\title{
Delivering the UK Energy Transition with an Accountable and Competitive Electricity Sector: Theory and Realities
}

Le Secteur britannique de l'électricité face à la transition énergétique : la responsabilité publique mise à l'épreuve

Lucie de Carvalho

\section{(2) OpenEdition}

\section{Journals}

Electronic version

URL: https://journals.openedition.org/rfcb/7932

DOI: $10.4000 /$ rfcb.7932

ISSN: 2429-4373

Publisher

CRECIB - Centre de recherche et d'études en civilisation britannique

Electronic reference

Lucie de Carvalho, "Delivering the UK Energy Transition with an Accountable and Competitive Electricity Sector: Theory and Realities", Revue Française de Civilisation Britannique [Online], XXVI-2 I 2021, Online since 05 January 2021, connection on 05 January 2022. URL: http:// journals.openedition.org/rfcb/7932 ; DOI: https://doi.org/10.4000/rfcb.7932

This text was automatically generated on 5 January 2022.

\section{$\Theta \Theta \Theta \Theta$}

Revue française de civilisation britannique est mis à disposition selon les termes de la licence Creative Commons Attribution - Pas d'Utilisation Commerciale - Pas de Modification 4.0 International. 


\title{
Delivering the UK Energy Transition with an Accountable and Competitive Electricity Sector: Theory and Realities
}

\author{
Le Secteur britannique de l'électricité face à la transition énergétique : la \\ responsabilité publique mise à l'épreuve
}

Lucie de Carvalho

\section{Introduction}

1 In June 2019, the May government ramped up their efforts to set ambitious targets to phase out fossil fuel energies from the domestic energy mix by amending the 2008 Climate Change Act. The amendment established a new legally-binding target of net zero greenhouse gas emissions by 2050, in line with the 2016 Paris Agreement. As things now stand (in mid-2020), UK greenhouse gas emissions have dropped by $43 \%$ since 1990, meaning that the country is well underway to meet its 2022 target; yet, projections beyond this first yardstick do not look as encouraging. As climate change mitigation has become increasingly pressing, electricity efficiency and sustainability have attracted intense political and academic interest since the energy sector stands at the forefront of any transition to a low-carbon economy. Today more than ever, these two issues have become symbiotically interrelated, as "you cannot deal with climate change without dealing with energy, and you cannot deal with energy without dealing with climate change", as Lord Deben recently stated. ${ }^{1}$

2 For the past 12 years, electricity and climate reforms have thus formed two sides of the same coin. From the 2008 Climate Act to the 2012 Electricity Market Reform, ${ }^{2}$ the 2016 Paris Agreement and the more recent 2019 Net-Zero Roadmap, ${ }^{3}$ recent UK governments have sought to reform the UK energy system to adapt it to the new demands of the 
ecological transition and to face the challenges of what is now known as 'the energy trilemma', namely affordability, security of supply, and sustainability. ${ }^{4}$ Affordability relates to the electricity sector's core function as a public good and a matter of public interest, since electricity services are critical, not only to sustain economic and industrial activity, but also to guarantee a decent standard of living for all.

Yet, tackling the energy trilemma does not only involve political decisions or leaps in technological innovations; it also requires popular trust and political leadership. In 2017, a research paper on UK public attitudes towards the energy transition by Demski et al concluded that public acceptance was not only affected by immediate pragmatic concerns, such as affordable prices; it was affected by value-laden priorities, such as equitable cost-sharing, and trust: it has to do with whom respondents deemed responsible for making the necessary changes to the UK energy system. ${ }^{5}$ Public acceptance is thus entrenched in the founding principle of accountability.

4 Now, although accountability is one of the most frequent concepts used in administrative literature, it is also one of the most difficult to define. ${ }^{6}$ Its very definition varies, and goes much beyond the most immediate meaning of accounting or being responsible for a specific action or behaviour. ${ }^{7}$ A running thread in accountability literature connects this concept to imperatives of integrity, responsibility, ethical and professional standards, control and popular oversight - all of them included in the democratic concept of 'good governance'. ${ }^{8}$ Accountability dynamics are visible through performance and efficiency scrutiny, regulation, and transparent reporting to determine "who does what and why?". ${ }^{9}$ In short, accountability involves five key components to uphold public interest: a) institutional frameworks and environment; b) clearly allocated responsibilities and duties and clearly established mandates; c) clearly defined expectations according to public interest imperatives; d) established scrutiny procedures and capability leading to potential sanctions and penalties in case of failure; and e) a solid degree of social participation in regulatory decisions. ${ }^{10}$

5 For public services, accountability underpins a system of checks and balances, which plays out between four major poles of actors expected to act for the public interest: public administration (government, parliament, the civil service), the courts of law, vested industrial interests, and consumers. At a crossroads between all four stands another key actor, the regulator, expected to operate independently from political, industrial or financial interests, ${ }^{11}$ and, theoretically at least, be vested with a statutory capacity to demand answers and enforce sanctions. ${ }^{12}$

Given the many challenges the energy transition and climate change mitigation policies have raised about accountability in the UK electricity sector, this article offers to explore how new public management restructuring has impacted the regulator's and the executive's mandate, authority, and capacity to address new climate imperatives while upholding taxpayers' interests. The aim will be to assess whether accountability dynamics have acted as a facilitating or a hampering variable on the country's path to decarbonisation and whether accountability mechanisms have proven efficient enough to scrutinise both the government and the regulator. Since regulation can be either pre-emptive or reactive, I shall look into two separate regulation stages, on the one hand, policy formulation and on the other, policy implementation. 


\section{The Impact of Privatisation on Accountability in the UK Electricity Sector}

\section{Towards the network accountability paradigm}

7 The UK electricity sector underwent major structural and regulatory upheavals through the 1989 Electricity Act as part of the third step in Thatcher's privatisation campaign. Market liberalisation, often dubbed deregulation, was completed when an independent regulatory authority was established, offer (the Office of Electricity Regulation). The mandate of the regulator was three-fold: first, it was expected to regulate the enduring monopolistic network companies to guarantee 'good value for money' through cost-efficiency and good customer services; second, to monitor competition for generation and supply markets to mitigate oligopolistic activities and market failures in the newly-privatised electricity market; "finally, the regulatory body was to guarantee supply security and sustainability for present and future generations of consumers" ${ }^{13}$ In short, the regulator was entrusted with fiduciary duties, alongside Parliament and the government, while service-delivery functions were removed "from public administration and [contracted] out to firms operating in the private sector". ${ }^{14}$

8 Often held up as a textbook example of a successful case study, the UK has regularly been praised as "the poster child of energy market liberalisation," 15 for its pioneering approach to electricity regulation by economists and energy experts alike. The early success of privatisation has mostly been ascribed to Offer's initial strategy to embrace 'incentive regulation'. By leaving private utilities flexibility to improve service efficiency, this strategy was the epitome of the "light-handed approach to electricity regulation' embraced by offer and promoted by its first director (1989-1998), renowned British economist Stephen Littlechild. The regulator would rather set price caps for generation than go for more rigid rate-of-return regulation. According to Littlechild, the regulator's prime focus should be to abide by the motto "competition where possible, regulation where not". ${ }^{16}$ Offer therefore took a backseat in regulation, only interfering when concerns over market dominance for electricity generation erupted, as was the case in 1994 when Offer compelled two generating utilities, National Power and Powergen, to sell off $6,000 \mathrm{MW}$ capacity to avoid market duopoly. Overall, price caps were thus key mechanisms for Offer to protect the interests of consumers, given that privatisation did not fully achieve its original purpose, namely to break down monopolies and foster natural competition between companies to lower prices. ${ }^{17} \mathrm{How}$ have 1990s' reforms affected accountability?

9 Privatising and liberalising the UK energy sector featured as a prime example of key principles of New Public Management (NPM) gaining ground in UK politics. The impact of NPM theories on the electricity sector were first the introduction of managerial imperatives into public services provision, now geared towards the rationalisation of public action through budget-keeping, target-setting and short-term strategic planning. Besides, the new constellation of public-private energy actors was meant to foster more transparency, plural accountability and participatory involvement in proceedings and decision making by establishing new sources of accountability. ${ }^{18}$ Dalingwater described deregulation as "disaggregation, which refers to the strengthening of central strategic capacity by decoupling policy and executive functions; tighter central control over policy and frameworks and a move from concentrating on process to output in control and 
accountability mechanisms." ${ }^{19}$ A key part of this dynamic, the electricity regulator, was established as an arm's length body, theoretically independent from executive or ministerial oversight to inject more transparency and impartiality into the energy sector and thus foster confidence from both the public and sectorial interests. This structural reform came to be known as the 'accountability-network paradigm'. ${ }^{20}$

\section{The limits of accountability-network reforms: grey zones and accountability loopholes}

10 Despite its first successful results, the UK experimental regulatory regime soon attracted academic criticism. ${ }^{21}$ Although the regulator's mandate was rather clear theoretically speaking, its action capacity has remained limited in practice, as its powers have been limited to prosecutorial and adjudicatory powers without being granted rule-making prerogatives, still vested in government. Furthermore, as for most arm's length bodies, Offer's directors-general have been appointed by the Secretary of State for the Department of Trade and Industry - a recruitment process that has been the target of much criticism not only for the lack of public oversight, ${ }^{22}$ but also because it has turned out that regulation directions have been quite subservient to the approach and the personality of the director-general, as demonstrated by Littlechild's influence over Offer's original trajectory. Finally, regulatory oversight remained isolated at the national level, limiting its accountability to local authorities. In that sense, the British regulatory approach differed greatly from the US regime, in which regulatory authority was broken down and distributed between several regional regulatory commissions. ${ }^{23}$ In other words, decentralisation of service delivery was not accompanied by decentralisation of decision making or even revenue allocation.

11 Moreover, NPM reforms have not provided a clear answer to who is accountable for what and how. By separating executive and regulatory remits, the establishment of independent quangos like offer created an institutional in-betweenness for accountability. If they became more independent from ministerial encroachment, quangos also eroded Ministers' leverage to make their frontline services accountable, offsetting all the unquestionable democratic virtues of independent regulation. ${ }^{24}$ Moyes also adds that: ${ }^{25}$

This fracturing of responsibility and accountability would see Ministers remaining accountable to Parliament without having control or even, necessarily, the basis to intervene, and commissioners, providers or regulators potentially exercising control without being accountable to Parliament.

Furthermore, the complexity of current policy matters has also inflated the departmental silo effect, whereby responsibilities over certain policy areas cut across several departmental boundaries, thereby creating a dispersion of accountability. Although Ofgem is sponsored by the department in charge of energy matters, electricity regulation for instance is not only the remit of the present Department of Business, Energy and Industrial Strategy; it can also be connected, among other things, to environmental matters, land planning, health, or devolved questions.

Finally, an extensive literature on the matter has raised the alarm about the introduction of private actors defending separate vested interests that do not necessarily align with the public interest due to inherently diverging ambitions. Although, as Farnetti noted, "[a] public-sector company is not necessarily a not-for-profit 
company, and a private-sector company is not necessarily a for-profit company," 26 it is safe to say that private actors, such as electricity generation or supply utilities, remain driven by value creation and marketability. They are first and foremost accountable to their shareholders before their contractors, while essential public services like electricity provision are geared towards good value for money, but also the defense of the public interest.

14 As called out in a 2014 report from the Public Administration Committee, the institutional system thus remains "full of anachronisms and anomalies" 27 and tensions abound regarding the actual precinct and responsibilities of each authority. Instead of improving accountability, these reforms further inflated the chameleonic nature of the concept due to the fact that much is still left to each actor's interpretation and shaped by the country's regulatory and policy culture. ${ }^{28}$ Consequently, to assess accountability in electricity regulation since 2010, we need to look at specific episodes when good governance debates over climate change mitigation have surfaced, starting with the first stage of regulation: policy design.

\section{Policy Design: the Impact of the Sustainability Agenda on Policy Directions and Decision-Makers' Mandates}

15 By the early 2010s, the pace of target-setting quickened as a flurry of new roadmaps and carbon reduction targets bridged Labour and the Coalition's tenures. This new climate change agenda impacted the relations between the government, the electricity utilities, Parliament and the regulator, by introducing a new goal in domestic policy, that of striving to roll in sustainability on top of vetting efficiency and price mitigation. Given that $27 \%$ of greenhouse emissions are produced by the energy sector, responsibility to shift primary electricity generation from fossil fuels to green energy sources, renewables and nuclear power, has befallen both markets and government.

The energy transition thus stood as a major accountability test for the government since failure to meet such statutory objectives would then be ascribed not only to industry and market participants but also to the government. In the context of liberalised markets, the primary role of the government as a policy designer was thus to set clear directions and make sure that transparency and confidence were firmly established, to guarantee that industry utilities would take on the risks of changing their operating practices.

17 Government policy came in the form of the 2012 Electricity Market Reform, which aimed at overhauling the rules of the market game to meet the energy trilemma. The reform spelt out stronger state intervention in the electricity market through the use of specific market mechanisms to steer electricity utilities towards low-carbon production and boost private investments in renewables by the late 2020s. In order to compensate utilities for potential labour and effective costs of sustainability incurred by staff training, potential job losses, technical improvements and overall need for investments to shore up domestic wind and nuclear energy capacity, the 2013 Reform entrenched the use of two specific subsidy schemes, the Contract-for-Difference (CfD) and Feed-in-Tariffs (FiT). 


\section{Scrutinising government electricity policy through judicial oversight} December 2011 and March 2012 obtained a 25-year guaranteed FiT, as originally planned. Undeterred by this first failure, the Government attempted to introduce another cut in FiTs in August 2012, leading to a new instalment in the legal battle between the government and solar industry companies, resulting in the 2015 DECC $v$. Breyer Group PLC and Others case ruled by the Supreme Court of Judicature. ${ }^{33}$ In this court ruling, UK judges gave a slightly different assessment of DECC's 2011 decision, arguing that the fundamental fault lay in the fact that DECC's measure went against the 1998 Human Rights Act upholding the right to goodwill. In this case, 'marketable goodwill' is to be understood as a 'possession' thus protected by the right to property. ${ }^{34}$ By providing retrospective changes to the economic foundation of solar energy investment, DECC thus acted ultra vires, interfered with "this possession" and violated the ECHR.

In short, these various judicial cases presented before Britain's most senior judges contributed to avoiding setting a most dangerous precedent by preventing the 
government from unilaterally altering incentive mechanisms, even more so as those mechanisms were still deemed crucial to ensure the industry's survival. At that stage, all indicators revealed that the private sector was indeed unable to shoulder the cost of expanding the solar industry alone. A 2013 DECC report on Renewable Roadmap would later confirm that roughly $£ 100$ to 110 billion needed to be injected into the electricity sector by 2020 to meet the $15 \%$ renewables target. ${ }^{35}$ These court rulings also testified to the efficiency of judicial oversight, by holding the government to account. They demonstrated that government action encroached on property rights, and that the public-interest or value-for-taxpayers'-money rational was void. Eventually, the government's unilateral decision to pick the winners and only sponsor offshore wind and nuclear power came through the UK's project in 2016 to build new nuclear power plants, as the subsidy scheme came to its natural end and was not renewed in 2018. ${ }^{36}$ In short, the Supreme Court and the lower Courts have upheld the founding principles of ministerial and executive accountability. Just like any parliamentary proceeding, energy decisions are judiciable and bound not only by convention or practices, but also by constitutional law. These cases provide further evidence that the UK senior courts are morphing into constitutional courts whose primary mandate is to defend democratic oversight and accountability. As Hogarth contends, these two cases can be seen as crowning precedents indicating that the courts, including the Supreme Court, had become: ${ }^{37}$

a guardian of democracy in the UK, policing the boundaries of constitutionally proper behaviour. Any ministers tempted to defy constitutional norms or conventions should beware: The Supreme Court has put them on notice.

Yet, such a reassertion of ministerial and executive accountability to the courts remains inherently bound by either subsequent judicial decisions and the executive's alternative means of policymaking that may still incapacitate, override or limit the scope of judicial scrutiny.

\section{Scrutinising government electricity policy through parliamentary oversight}


249 industry, academic and public contributors. ${ }^{39}$ This new roadmap revealed that the Committee intended to further investigate the government's energy strategy in terms of consistency and transparency over subsidy schemes. In 2016, the Committee also issued a scathing report on Investor Confidence in the UK Energy Sector, here also challenging the Cameron government for their handling of energy subsidy schemes, deeming them to have seriously harmed investor confidence and the UK's attractiveness. The government's sudden changes of heart had "raised serious questions about the government's plans for meeting long-term carbon objectives". ${ }^{40}$

Yet, the investigative capability of this parliamentary select committee came to be restricted by executive reshuffling decisions. Its 2015 inquiry was interrupted by the 2016 referendum, and Theresa May's election to the party leadership led to the dismantling of DECC, as energy and climate change matters migrated to another newlyestablished department, the Business, Energy and Industrial Strategy Department. The new parliamentary BEIS committee, which began operating on 10 October 2016, has so far proven less keen to investigate energy regulation matters; the lines of scrutiny identified by their predecessors in their 2015 roadmap have been shelved and only one inquiry has been run so far on the government's Net-Zero policy since 2016.

Parallel to the now defunct ECC Select Committee, another statutory body, the Committee on Climate Change (CCC), has also been involved in scrutinising government policy since its inception in 2008 - even more since the ECC select committee was disbanded in 2016. Its original mandate was two-fold: first, to advise government on emission targets; and second, to report to parliamentary select committees on the progress made, thus acting as a bridge between the executive and the legislative powers. In the summer 2019, the CCC published two very critical reports, questioning the government's approach to meet the Net-Zero targets. In its second report, Reducing UK Emissions 2019 Progress Report to Parliament, the CCC renewed the central premise that "the government of the day holds the responsibility to act to protect future generations", as established through the 2008 Climate Change legislation. ${ }^{41}$ The report also revealed that the Committee found "a substantial gap between current plans and future requirements and an even greater shortfall in action." ${ }^{42}$ This report thus called the government out on their inconsistent approach of establishing a Net-Zero target while at the same time disbanding DECC and downgrading climate change as a secondary policy priority. Yet, just like that of the Select Committee, the CCC's work has remained fundamentally advisory in nature, generating little reaction from the government. Consequently, parliamentary accountability seems restricted to a conventional process that is pursued with more or less interest by the MPs involved with little sanction capacity, potentially reducing MPs to barking dogs without biting power. Overall, parliamentary oversight of executive and ministerial decisions thus remains a transparency device that has restricted Parliament's capacity to check the government's progress and policy decisions.

Overall, the government's decision-making mandate has been scrutinised by "multiple accountabilities", be they judicial (the Courts), political (Parliament's select committee), or advisory (the $\mathrm{CCC}$ ). The examples presented tend to suggest that government accountability to these bodies remains fundamentally elusive, diluted in a "tangled web" of accountability. ${ }^{43}$ Partisan bias could be a likely parameter determining Parliament's degree of involvement in questioning the government's steps to meet the demands of 
the energy trilemma, to quicken the pace of the energy transition, through affordable prices, and long-term sustainability.

Since 2010, the UK government has thus sent very contradictory signals and the judicial and parliamentary responses to their policy have nonetheless dented political credibility and predictability, in turn undermining market and investor confidence. As Heller and McCubbins underlined: ${ }^{44}$

incentives for investing in infrastructure industries are not credible within a given regulatory structure unless there is a political context that makes them sustainable. Regulatory predictability is a key feature for gaining credibility, and hence the important role of political institutions in enhancing this predictability.

Let us now turn to a second regulatory stage, policy implementation to examine the electricity regulator's accountability.

\section{Policy Implementation: the Effectiveness of Ofgem as a Regulatory Watchdog}

\section{Ofgem's waning ability to protect consumer interest}

33 At the other end of the policy spectrum, electricity reforms will most likely affect consumers through price variations. Recent literature on decarbonisation has demonstrated that transition to a low-carbon economy, whatever the pathway chosen, will be costly. ${ }^{45}$ Ever since the early 1970s, energy prices and affordability have been a continual public and political concern. A 2014 YouGov survey revealed that energy prices were the third top political concern of $40 \%$ of the respondents, behind the economy (59\%) and immigration (49\%). ${ }^{46}$ According to a study run on public perceptions about accountability for energy prices, Demski et al. showed that most respondents believed that energy utilities, despite being bound by their public service mandate, were not trustworthy and not "contributing their share to fund the energy transition." ${ }^{47}$ As previously stated, private companies have little to no interest to lower their prices, as it narrows their profit margins. That is one of the reasons why the UK's approach to electricity regulation has been geared towards price regulation, under the responsibility of the regulator, Ofgem (which replaced Offer in 2000).

Since the rise of climate change concerns and the introduction of climate change legislation in the late 2000s, Ofgem has faced mounting criticism over its independence and autonomy from executive control, thus challenging its mandate as guardian of consumer interest against political and sectoral interest: ${ }^{48}$

Firstly, in an analysis of Ofgem's Decarbonisation Action Plan published in February 2020, John Constable argued that Ofgem had demonstrated very little interest in actually running independent cost analyses, as the report only relied on government's cost assessment. ${ }^{49}$ Similarly, Constable contends that the same report "argues that costs of wind generation will fall in the long term without referring to debates in academic circles about it, nor does it question the success of the CfD contracts." And yet why would they, especially considering the present CEO's background: before being appointed Ofgem CEO in October 2019, Jonathan Brearley was part of Tony Blair's Prime Minister Strategy Unit; between 2006 and 2009, he headed the Office of Climate Change, which contributed to drafting the 2008 Climate Change bill, and from 2009 to 2013, he was Director of Energy Markets and Infrastructure Networks, operating within DECC. Brearley actually was a 
key architect of the Energy Market Reform and a major proponent of the very same $C f D$ systems in 2012, which Ofgem has been expected to scrutinise. ${ }^{50}$ In other words, his previous involvement in climate-change policy making could constitute a potential conflict of interest and compromises his impartiality and independence.

Finally, the 2010-2012 reforms have actually infringed on Ofgem's capacity to guarantee electricity affordability in the defence of consumer interests. The 2010 Electricity Act indeed amended the very definition of 'consumer interest', which no longer merely covers "the interests of existing and future consumers" in a competitive environment, as defined in the 2000 Utilities Act, but also now states that those interests are subservient to the need to reduce greenhouse gas emissions and guarantee supply security. It follows that the 2010 Act in effect defanged Ofgem, preventing it from effectively challenging the government, even if it would later befall on consumers to foot the bill through price or cost hikes. Similarly, average electricity prices paid by UK households have been rising constantly since 2000 , soaring by $67 \%$ since 2000 , and by $20 \%$ since $2007 . .^{51}$ Ofgem has thus shown little capacity to either rein in the six major electricity utilities, or incentivise them to lower their prices while curbing their greenhouse gas emissions..$^{52}$ Evidence thus tends to suggest that decarbonisation has greatly eroded Ofgem's capacity to bring either the government or the utilities to account, and the other way round: ${ }^{53}$ consumer interests have be sacrificed to the demands of the government's green agenda. In line with the original light-regulation approach embraced in the early 1990s, Ofgem has implicitly embraced the Machiavellian imperative that, in the context of decarbonisation, the end justifies the means.

\section{When heads must roll: accountability for electricity blackouts}

37 A final avenue to test sectoral accountability in policy implementation would be operational failure. In the electricity sector, blackouts are a good example, as accountability involves identifying where the responsibility lies to make sure 'lessons have been learned'. Due to their spectacular consequences, blackouts often attract intense media attention, as was the case in May 2008, ${ }^{54}$ December $2013^{55}$ and August 2019 when a gas power station and a windfarm unexpectedly went into shutdown, leading to severe disruption in public transport and leaving over one million households in England and Wales without electricity for up to 9 hours.

In these instances, scrutiny immediately fell on both the National Grid and the regulator. The subsequent inquiries and investigations into the 2019 outage, the biggest in the decade, failed to provide a clear view of the situation as each actor engaged in a blame-game to avoid shouldering the cost of compensating customers. ${ }^{56}$ The focus of attention was directed at the National Grid's responsibility and the inherent conflict of interest rising from the fact that the National Grid owns and operates energy transmission infrastructures in the UK and interconnectors with the Continent, while also being in charge of balancing electricity supply and demand. For the Labour Opposition, this instance furthered their renationalisation agenda as calls to counter privatisation have gained momentum within Labour ranks, especially under Jeremy Corbyn's leadership.

In other words, the 2019 power blackout reignited debates over structure, ownership and role assignment. Yet investigations failed really to investigate further the technological capability or resilience, let alone sustainability, of the UK electricity 
network. By directing all political and media attention onto one specific stakeholder in a fundamentally interconnected system, the government somehow deflected attention away from the question of government investment in technological innovation.

All in all, accountability at the delivery stage seems more geared towards immediate blame and sanction, rather than learning lessons; while media attention was shortterm, little political reaction actually emerged in the wake of the outage - Parliament's BEIS Select Committee did not launch any inquiry and the matter seems today to have been overshadowed by other more pressing issues. Yet, this recent blackout episode brings to light the political nature of accountability which "overemphasises the role of blame in holding individuals and organisations to account. This, ironically, undermines the focus on improvement that the public wants to see following failures." ${ }^{57}$

\section{Conclusion}

This article has aimed to identify the impacts of NPM reforms on accountability in electricity services in the light of the present decarbonisation agenda. Rather difficult to fully delineate in practice, accountability remains both an ideal and a democratic imperative embedded in rules, practices, frameworks, but also in culture. NPM reforms were primarily justified as a means to solve "the problems of remoteness, unresponsiveness, and unaccountability associated with twentieth-century nationalised industries" ${ }^{58}$ Yet the present case study suggests that they have not fully met their original purposes.

NPM reforms have not fundamentally deconstructed the existing regulatory and accountability culture in Britain. The previous vertical, executive-centred, commandand-control decision-making pattern has endured; unremitting executive interference has made economic and political interest hard to reconcile with sustainability, while the other institutional or statutory sources of accountability have shown little leverage to influence governmental policies. On the one hand, although parliamentary and judicial oversight has proven rather efficient in calling the government out on their policy inconsistencies and their lack of staunch support for the renewable energy industry, their scope remains limited due to inbuilt time limitations, be they parliament's lifespans or procedural restrictions, and their enduring ad hoc nature. Nevertheless, evidence tends to suggest that Britain's parliamentary democracy is growing increasingly legalistic. ${ }^{59}$ On the other hand, due to an enduring lack of independence, the regulator's leverage has progressively been eroded along with its capabilities to monitor and bring either private service providers or the government to account. Recent policy changes tend to suggest that climate change mitigation has pushed the key component of affordability onto the backburner, sapping Ofgem's drive to act in the consumers' interest.

Although service reliability and performance have improved since privatisation, electricity prices continue to follow an upward trend ${ }^{60}$ and the issue of fuel poverty has been gaining increasing academic and media attention. Given that affordability, energy prices and the question of ownership are fundamentally ideologically driven, being tightly intertwined with issues of equity, public interest and social justice, climate change mitigation has not depoliticised accountability in energy questions - quite the opposite. 


\section{BIBLIOGRAPHY}

Auby, Jean-Bernard, 'Contracting Out and 'Public Values': a theoretical and comparative approach,' in Rose-Ackerman, Susan and Lindseth, Peter (eds), Comparative Administrative Law (Farnham, Ashgate Publishing, 2010).

Bovens, Mark, 'Public Accountability', in Ewan Ferlie, Ewan, Lynn, L., and Pollitt, C. (eds), The Oxford Handbook of Public Management (New York, Oxford University Press (USA), 2007), pp. 182-208.

Adrian Brügger, Adrian, Dessai, S., Devine-Wright, P., Morton, T. and Pidgeon, N., "Psychological responses to the proximity of climate change", Nature Climate Change 5, 2015, pp. 1031-1037.

Capalbo, Fransesco and Palumbo, Ricardo "The imperfect match of public accountability of stateowned entreprises and private-sector-type financial reporting" Australasian Accounting, Business and Finance Journal 7:4, 2013.

Committee on Climate Change, Reducing UK emissions - 2019 progress report to Parliament (London, CCC, July 2019).

Dalingwater, Louise, "Civil Service Reform and the Legacy of Thatcherism" Observatoire de la société britannique 17, 2015, pp. 61-78.

Demski, Christina, Evensen, D., Pidgeon, N., and Spence, A., "public prioritisation of energy affordability in the UK", Energy Policy 110, 2017, pp. 404-409.

DECC, UK Energy in Brief (London, Stationary Office, 2011).

DECC, Planning our Electric Future: a White Paper for Secure, Affordable and Low-Carbon Electricity (London, Stationary Office, 2010).

DECC, Renewable Energy Roadmap Update (London, Stationary Office, 2013).

DECC, Estimated impacts of energy and climate change policies on energy prices and bills (London, Stationary Office, March 2013).

Dixit S., et al., "The Electricity Governance Toolkit: Benchmarking Best Practice and Promoting Accountability in the Electricity Sector," (Washington, the World Resources Institute, June 2007) p.7.

Dubnick, Melvin and Frederickson, George (eds.), Accountable Governance: Problems and Promises (New York, Sharpe, 2011).

Energy and Climate Change Committee, Oral Evidence: Committee on Climate Change: 2015 Progress Report to Parliament, House of Commons 462 (London, SOL, 15 September 2015).

Energy and Climate Change Committee, Our Priorities for Parliament 2015-2020, House of Commons 368 (London, Stationary Office, 18 December 2015).

Energy and Climate Change Committee, Investor Confidence in the UK energy Sector, Third Report of Session 2015-2016, HC 542 (London, Stationary Office, 3 March 2016).

Energy Information Association, Electricity Reform Abroad and US Investments (US Department of Energy, Washington, 1997).

Flinders, Matthew, The Politics of Accountability in the Modern State, Routledge, Abingdon, 2018, $2^{\text {nd }}$ Edition. 
Gasmi, Faid, Noumba Um, P. and Recuero Virto, L., Political Accountability and Regulatory Performance in Infrastructure Industries: An Empirical Analysis, Research Working Paper $\mathrm{n}^{\circ}$ WPS 4101 (Washington DC, World Bank, 2006).

Guerin, Benoit, McCrae, J., and Shepheard, M., Accountability in Modern Government: What are the Issues, (London, Institute for Government, April 2018).

Hall, David, "Public Ownership of the UK energy System - benefits, costs and processes" PSIRU (April 2016).

Haney Aoife Brophy and Pollitt, Michael, "Dismantling a Competitive Electricity Sector: The U.K.'s Electricity Market Reform” Electricity Journal, 26:10, 2013.

Hannon, Matthew et al., "The co-evolutionary relationship between Energy Service Companies and the UK energy system: Implications for a low-carbon transition” Energy Policy 61, 2013.

Heritier, Adrienne and Rhodes, Martin, 'New Modes of Governance', in Adrienne Heritier and Martin Rhodes (eds), New Modes of Governance in Europe: Governing in the Shadows of Hierarchy (London, Palgrave, 2011).

House of Lords Select Committee on the Constitution, The Regulatory State: Ensuring its Accountability, $6^{\text {th }}$ Report of Session 2003-2004 (London, Stationary Office, 2003).

Littlechild, Stephen, "Foreword: The Market versus regulation" in Sioshansi, Fereidoon and Pfaffenberg, Wolfgang (eds), Electricity Market Reform: An International Perspective (Oxford, Elsevier Science Ltd, 2006).

Meeus, Leonardo and Glachant, Jean-Michel (eds), Electricity Network Regulation in the EU: The Challenges ahead for Transmission and Distribution (Cheltenham, Edward Elgar Pub, 2018).

Moyes, William, Woods, Julian and Clemence, Michael Nothing to Do with Me? Modernising Ministerial Accountability for Decentralised Public Services (London, Institute for Government, 2011).

Mulgan, Richard, “Accountability: An Ever-Expanding Concept?’ Public Administration 78:3, 2000, pp. 555-573.

OECD, Reviews of Regulatory Reforms: UK 2002, Challenges at the Cutting Edge (Paris, OECD, 2002), Ofgem, Energy Supply Probe- Initial Findings Report (London, Office of Gas and Electricity Markets, 2008).

Public Administration Select Committee, Fourteenth Report of Session 2010-12, Public Appointments: regulation, recruitment and pay, HC 1389 (London, Stationary Office, 2010).

Pye, Steve, Sabio, N. and Strachan, N., UKERC Energy Strategy Under Uncertainties: An Integrated Systematic Analysis of Uncertainties in UK Energy Transition Pathways (London, UK Energy Research Centre, 2014).

Roberts, John, and Scapens, Robert, “Accounting Systems and Systems of Accountability: Understanding Accounting Practices in Their Organisational Contexts', Accounting, Organizations and Society 10:4, 1985, pp. 443-456.

Schedler, Andreas, Diamond, L. and Plattner, M. (eds), The Self-Restraining State: Power and Accountability in New Democracies (London, Lynne Rienner Publishers, 1999).

Sinclair, Amanda, "The chameleon of accountability: Forms and discourses", Accounting, Organizations and Society 20:2-3, 1995, pp. 219-237. 
Steinberger, Julia and van Niel, Johan, "Profiting from megawatts: reducing absolute consumption and emissions through a performance-based energy economy" Energy Policy 37:1, 2009, pp. 361-370.

Ward, Michael et al., "Network Analysis and Political Science" Annual Review of Political Science 14:245, 2011, pp. 248-49.

\section{NOTES}

1. Energy and Climate Change Committee, Oral Evidence: Committee on Climate Change: 2015 Progress Report to Parliament, House of Commons 462 (London, SOL, 15 September 2015).

2. The 2012 Electricity Market Reform will be presented in more details further below.

3. The Net-Zero roadmap aimed to identify several pathways to allow the UK to meet its 2050 netzero emissions target while guaranteeing sound economic opportunities.

4. Adrian Brügger, Suraje Dessai, Patrick Devine-Wright, Thomas Morton, and Nicholas Pidgeon, "Psychological responses to the proximity of climate change", Nature Climate Change 5, 2015, pp. 1031-1037.

5. Christina Demski, Darrick Evensen, Nicholas Pidgeon, and Alexa Spence, "Public prioritisation of energy affordability in the UK", Energy Policy 110, 2017, pp. 404-409.

6. Amanda Sinclair, "The chameleon of accountability: Forms and discourses", Accounting, Organizations and Society 20:2-3, 1995, pp. 219-237.

7. John Roberts and Robert Scapens, "Accounting Systems and Systems of Accountability: Understanding Accounting Practices in Their Organisational Contexts', Accounting, Organizations and Society 10:4, 1985, pp. 443-456.

8. Richard Mulgan, “Accountability: An Ever-Expanding Concept?' Public Administration 78:3, 2000, pp. 555-573.

Mark Bovens, "Public Accountability", in Ewan Ferlie, Laurence Lynn and Christopher Pollitt (eds), The Oxford Handbook of Public Management (New York, Oxford University Press (USA), 2007), pp. 182-208.

9. House of Lords Select Committee on the Constitution, The Regulatory State: Ensuring its Accountability, $6^{\text {th }}$ Report of Session 2003-2004 (London, Stationary Office, 2003), p. 6.

10. Shantanu Dixit et al., "The Electricity Governance Toolkit: Benchmarking Best Practice and Promoting Accountability in the Electricity Sector," (Washington, the World Resources Institute, June 2007) p.7.

11. Faid Gasmi, Paul Noumba Um and Laura Recuero Virto, Political Accountability and Regulatory Performance in Infrastructure Industries: An Empirical Analysis, Research Working Paper $n^{\circ}$ WPS 4101 (Washington DC, World Bank, 2006), p. 9.

12. Andreas Schedler, Larry Diamond and Mark Plattner (eds), The Self-Restraining State: Power and Accountability in New Democracies (London, Lynne Rienner Publishers, 1999), p. 21.

13. Leonardo Meeus and Jean-Michel Glachant (eds), Electricity Network Regulation in the EU: The Challenges ahead for Transmission and Distribution (Cheltenham, Edward Elgar Pub, 2018), p. 5.

14. Jean-Bernard Auby, 'Contracting Out and 'Public Values': a theoretical and comparative approach,' in Susan Rose-Ackerman and Peter Lindseth (eds), Comparative Administrative Law (Farnham, Ashgate Publishing, 2010) p. 511.

15. Aoife Brophy Haney and Michael Pollitt, "Dismantling a Competitive Electricity Sector: The U.K.'s Electricity Market Reform” Electricity Journal, 26:10, 2013, p. 8.

OECD, Reviews of Regulatory Reforms: UK 2002, Challenges at the Cutting Edge (Paris, OECD, 2002), p. 31. 
16. Stephen Littlechild, "Foreword: The Market versus regulation" in Fereidoon Sioshansi and Wolfgang Pfaffenberg (eds), Electricity Market Reform: An International Perspective (Oxford, Elsevier Science Ltd, 2006).

17. Ofgem, Energy Supply Probe- Initial Findings Report (London, Office of Gas and Electricity Markets, 2008).

18. Adrienne Heritier and Martin Rhodes, 'New Modes of Governance', in Adrienne Heritier and Martin Rhodes (eds), New Modes of Governance in Europe: Governing in the Shadows of Hierarchy (London, Palgrave, 2011), p. 163.

19. Louise Dalingwater, "Civil Service Reform and the Legacy of Thatcherism" Observatoire de la société britannique 17, 2015, pp. 61-78.

20. Michael D. Ward et al., "Network Analysis and Political Science" Annual Review of Political Science 14:245, 2011, pp. 248-49.

21. Irwin M. Stelzer, "Lessons from UK Regulation from recent US experience," in Michael Beesley (ed.), Regulating Utilities: Time for Change? (London, The Institute of Economic Affairs, 1996), p. 194.

22. Public Administration Select Committee, Fourteenth Report of Session 2010-12, Public Appointments: regulation, recruitment and pay, HC 1389 (London, Stationary Office, 2010).

23. Energy Information Association, Electricity Reform Abroad and US Investments (US Department of Energy, Washington, 1997) p. 333.

24. William Moyes, Julian Woods and Michael Clemence, Nothing to Do with Me? Modernising Ministerial Accountability for Decentralised Public Services (London, Institute for Government, 2011), p. 2.

25. Ibid., p. 23.

26. Quoted in: Fransesco Capalbo and Ricardo Palumbo, "The imperfect match of public accountability of state-owned entreprises and private-sector-type financial reporting" Australasian Accounting, Business and Finance Journal 7:4, 2013, p. 38.

27. Nick Hurd MP, quoted in: House of Commons Public Administration Committee, "Who's accountable for what? Relationships between government and arm's-length bodies", First Report of Session 2014-2015 (London, Stationary Office, 2014), p. 9.

28. Amanda Sinclair, "The chameleon of accountability: Forms and discourses", Accounting, Organizations and Society 20:2-3, 1995, pp. 219-237.

29. DECC, Planning our Electric Future: a White Paper for Secure, Affordable and Low-Carbon Electricity (London, Stationary Office, 2010), p. 7.

30. Ernst \& Young, "Renewable energy country attractiveness indices" 33, May 2012.

31. Damian Carrington, "Solar subsidies cuts: UK government loses court appeal", The Guardian, 25 January 2011.

32. Justice John Mitting, High Court Ruling, 21 December 2011.

33. Supreme Court of Judicature (Lord Dyson, Lord Justice Richards, Lord Justice Ryder), the DECC and Breyer Group case n ${ }^{\circ}$ A3/2014/2909/2910,2913, 28 April 2015.

34. See court judgement, p. 7, <https://www.judiciary.uk/wp-content/uploads/2015/04/decc-vbreyer-judgment.pdf> [1 September 2020].

35. DECC, Renewable Energy Roadmap Update (London, Stationary Office, 2013), p. 21.

36. "Updated Feed-in Tariff timeline: the rise and fall of solar subsidies", Edie Newsroom, 15 December 2015, available at: https://www.edie.net/news/6/Feed-in-tariff-UK-solar-subsidiesGovernment-consultation/ consulted in March 2020.

Adam Vaughan, "Subsidies for new household solar panels to end next year", The Guardian, 19 July 2018.

37. Raphael Hogarth, "the Supreme Court has fortified Parliament's constitutional role - and its own", The Institute for Government, 25 September 2019, <https:// 
www.instituteforgovernment.org.uk/blog/supreme-court-fortified-parliaments-constitutionalrole-and-its-own> [12 February 2020].

38. Energy and Climate Change Committee, Oral Evidence: Committee on Climate Change: 2015 Progress Report to Parliament, House of Commons 462 (London, Stationary Office, 15 September 2015).

39. Energy and Climate Change Committee, Our Priorities for Parliament 2015-2020, House of Commons 368 (London, Stationary Office, 18 December 2015).

40. Energy and Climate Change Committee, Investor Confidence in the UK energy Sector, Third Report of Session 2015-2016, HC 542 (London, Stationary Office, 3 March 2016), p. 3.

41. Committee on Climate Change, Reducing UK emissions - 2019 progress report to Parliament (CCC, London, July 2019) p. 9.

42. Ibid, p. 8.

43. Melvin J. Dubnick and H. George Frederickson (eds.), Accountable Governance: Problems and Promises (New York, Sharpe, 2011) p. 23.

44. Quoted in: Faid Gasmi, Paul Noumba Um and Laura Recuero Virto, Political Accountability and Regulatory Performance in Infrastructure Industries: An Empirical Analysis, Research Working Paper $\mathrm{n}^{\circ}$ WPS 4101 (Washington DC, World Bank, 2006) p. 6.

45. Steve Pye, Ngore Sabio, and Neil Strachan, UKERC Energy Strategy Under Uncertainties: An Integrated Systematic Analysis of Uncertainties in UK Energy Transition Pathways (London, UK Energy Research Centre, 2014).

46. David Reiner, "Focus on British Attitudes to Energy Bills", YouGov-Cambridge Survey Results, April 2014, <https://yougov.co.uk/topics/science/articles-reports/2014/04/08/focus-britishattitudes-energy-bills> [January 2020].

47. Christina Demski, Catherine Butler, Karen A. Parkhill, Alexa Spence, Nick Pidgeon, "Public values for energy system change", Global Environmental Change 34 (2015), pp. 59-69.

48. Dr John Constable, "The decline and fall of Britain's energy regulator, Ofgem", The Global Warming Policy Forum, 4 February 2020, <https://www.thegwpf.com/the-decline-and-fall-ofbritains-energy-regulator-ofgem/> [March 2020].

49. Ofgem, 2020 Decarbonisation programme Action plan (London, Stationary Office, February 2020), p. 3.

50. See Brearley's 2012 presentation, <http://fes.nationalgrid.com/media/1327/ jonathanbrearleyelectricitymarketreform.pdf> [February 2020].

See: <https://utilityweek.co.uk/interview-jonathan-brearley-director-of-brearley-economicsand-the-architect-of-emr-while-at-decc/> [September 2020].

51. DECC, Estimated impacts of energy and climate change policies on energy prices and bills (London, Stationary Office, March 2013), p 8.

52. Julia Steinberger and Johan van Niel, "Profiting from megawatts: reducing absolute consumption and emissions through a performance-based energy economy" Energy Policy 37:1, 2009, pp. 361-370.

Matthew Hannon et al., "The co-evolutionary relationship between Energy Service Companies and the UK energy system: Implications for a low-carbon transition" Energy Policy 61, 2013, p. 1032.

53. David Hall, "Public Ownership of the UK energy System - benefits, costs and processes" PSIRU (April 2016), p. 3.

54. In May 2008 both the Sizewell B nuclear plant and the Longannet coal-fired station in Fife went offline, causing a major power outage.

55. The power outage occurred at Christmas 2013 due to severe weather, leaving tens of thousands of households without electricity for more than 24 hours.

56. Jillian Ambrose, "UK blackouts: MPs to question energy regulator's role", The Guardian, 19 September 2019. 
57. Benoit Guerin, Julian McCrae, and Marcus Shepheard, Accountability in Modern Government: What are the Issues, (London, Institute for Government, April 2018).

58. David Hall, "Public Ownership of the UK energy System - benefits, costs and processes" PSIRU (April 2016), p. 8.

59. Flinders, Matthew, The Politics of Accountability in the Modern State (Abingdon, Routledge 2018, $2^{\text {nd }}$ Edition), p. 170.

60. DECC, UK Energy in Brief (London, Stationary Office, 2011).

\section{ABSTRACTS}

This article discusses accountability in UK electricity services against the backdrop of the energy transition. Today's decarbonisation imperatives stand as a major accountability test for the UK government and the electricity regulator, which have been grappling with the energy trilemma since the early 2000s. The analysis will determine the extent to which both have responded to these new goals while still abiding by their original mandate to uphold the public interest. Climate change imperatives have actually brought to the surface enduring faulty accountability dynamics, which had at first been obscured - by practice or design - by the new public management reforms of the early 1990s. The inherently ad hoc and flexible British accountability culture therefore appears to have contributed to hampering the country's progress towards decarbonisation.

Cet article propose d'étudier la responsabilité publique (accountability) dans le secteur britannique de l'électricité, à la lumière de la transition énergétique. Les enjeux liés aux obligations de décarbonisation du système économique ont mis à l'épreuve la capacité du gouvernement britannique et de l'autorité de régulation de l'énergie à répondre à ce qu'on appelle communément le trilemme énergétique. Il s'agira d'analyser la façon dont ces nouveaux impératifs ont eu un impact sur leurs capacités à remplir leur mission publique de défense de l'intérêt général. Cette analyse démontre que les enjeux climatiques ont révélé des dysfonctionnements profonds en termes de responsabilité publique, que les réformes néolibérales des années 1980 avaient, volontairement ou involontairement, participés à occulter. La nature même de la culture britannique en matière de responsabilité publique, traditionnellement caractérisée par le pragmatisme et la flexibilité, apparaît ainsi comme un frein majeur à une mise en œuvre efficace de la transition énergétique.

\section{INDEX}

Keywords: accountability, electricity, decarbonisation, climate change, energy regulation Mots-clés: responsabilité, électricité, transition énergétique, règlementation de l'énergie 


\section{AUTHOR}

\section{LUCIE DE CARVALHO}

Université de Lille, CECILLE

Lucie de Carvalho is senior lecturer in British history and politics at the University of Lille. Her research focuses on contemporary British energy and environment policies (1979 to present). 